\title{
Marko Kerševan
}

\section{ISLAM IN MUSLIMANI V SEKULARIZIRANI EVROPI}

Nisem strokovnjak za islam, se pa dolga leta kot sociolog religije in religiolog ukvarjam $\mathrm{z}$ vprašanji mesta in vloge religij ter religioznega $\mathrm{v}$ družbah in kulturah, posebej sodobnih evropskih, ter razlikami in razmerjem med religijami pri tem. $S$ tega vidika in iz takega védenja se mi za obravnavo vprašanja islama v sekularizirani Evropi ${ }^{1}$ ponujajo tri izhodišča, recimo jim »situacijsko «, »sistemsko « in »zgodovinsko«. Skušal jih bom skicirati bolj v obliki tez ter ob njihovih stičiščih nakazati nekatere dileme in perspektive.

\section{"Situacijski« pristop}

V sodobni Evropi se muslimanom - tako tistim, ki so tu že tradicionalno, kot tistim, ki prihajajo - v načelu ni treba odpovedovati svoji religiji ali jo skrivati: $v$ načelu uživajo enako versko svobodo kot pripadniki drugih manjšin ali novih religij v tem prostoru. To pomeni, da lahko $\mathrm{v}$ njej živijo, vanjo prihajajo in $\mathrm{v}$ njej ostajajo kot muslimani, da lahko $\mathrm{v}$ njej izražajo svojo vero. Ta poudarek je potreben, ker ni bilo vedno tako,

1 Predavanje in članek temeljita na avtorjevem prispevku, napisanem za znanstveno konferenco Stoletje islamske skupnosti v Sloveniji (Ljubljana, 25. oktober 2017), ki jo je pripravil Kulturno-izobraževalni zavod Averroes Islamske skupnosti v Republiki Sloveniji; prispevek bo objavljen tudi v predvidenem zborniku konference. 
nasprotno, v zahodni krščanski Evropi vse do zadnjih stoletij muslimani s svojo vero niso obstali, drugače kot kristjani v islamskih deželah istega časa ... V načelu so kot državljani in/ali prebivalci deležni enakih pravic kot drugi državljani in prebivalci drugačnih religij in provenienc.

Verska svoboda - svoboda sprejemati in izražati, izbirati in spreminjati pripadnost neki religiji - je v moderni Evropi utemeljena in nerazdružno povezana $z$ drugimi temeljnimi načeli in vrednotami teh družb:

- s temeljno enakostjo in enakopravnostjo prebivalcev ne glede na raso, spol, etnično in religiozno pripadnost;

- svobodo vesti, govora, izpovedovanja vere in prepričanja;

- solidarnostjo posameznikov pri zagotavljanju te temeljne enakosti in svobode vseh.

Temu tako ali drugače »institucionaliziranemu individualizmu« služi tudi svetovnonazorska nevtralnost države, bolj ali manj dosledno izvedena ločenost države in državnih ustanov od religije ter religijskih ustanov.

Država, državna oblast in obvezne javne ustanove so »sekularne«, ne vežejo se na nobeno religijo, ne izpovedujejo nobene vere; nobene tudi ne zapovedujejo in ne prepovedujejo. Država naj skrbi "po meri človeških zmožnosti«, tudi z uporabo prisile, za "pravičnost in mir« (Barmenska deklaracija). Ljudje se kot državljani združujejo v države in vključujejo v državne ustanove za dosego tega in drugih posvetnih ciljev; za izpovedovanje (širjenje, uresničevanje) vere se združujejo v verskih skupnostih, ki za razliko od države ne razpolagajo s sredstvi zunanje prisile (Barth 2016).

Mirno in enakopravno sobivanje ljudi različnih religij zahteva/predpostavlja sprejemanje teh načel. Zahteva pa tudi (samo)omejevanje in medsebojno toleranco, v kolikor bi uresničevanje načel ene od religij ogrozilo enake pravice enakopravnega sobivanja ljudi drugih religij. Sprejemanje zgornjih načel sekularne države je pogoj za obstoj različnih religij in sobivanje ljudi različnih religij v teh družbah. Zrušenje teh načel neizogibno ogrozi preživetje ene ali druge religije ali celo njihovih 
pripadnikov. Sekularnost/laičnost države v službi temeljne enakosti in svobode državljanov je pogoj sobivanja religij in vernikov različnih religij. Vprašanje pri tem je, ali so različne religije in pripadniki različnih religij zmožni in pripravljeni sprejeti ta načela ter njihovo uresničevanje. Zgodovinska regresija: Možno je relativno mirno sobivanje različnih religij in vernikov tudi brez teh načel. Iz zgodovine ga poznamo v več oblikah: kot sobivanje različnih religijsko homogenih držav; kot sobivanje različnih religij s funkcionalno delitvijo pristojnosti različnih bogov, njihovih kultov in njihovih častilcev (bogov in kultov dinastije in $\mathrm{s}$ tem državne enotnosti, etničnih, lokalnih in rodbinskih kultov, bogov posameznih poklicev in čisto zasebnih kultov v rimskem imperiju, v indijskih in kitajskih "politeističnih" ali "panteističnih" kontekstih); sistem getov ali »miletski« sistem za pripadnike nedominantnih religij $\mathrm{v}$ družbah/državah $\mathrm{z}$ dominacijo ene od monoteističnih religij in $\mathrm{s}$ tolerantnostjo do drugih (judovski geto v krščanski srednjeveški Evropi, miletski sistem v osmanski islamski državi) (Corm 1977). Ukinitev ali velika erozija uresničevanja sekularnih načel bi pomenila zgodovinsko regresijo v take "rešitve« oziroma v postmoderne ekvivalente in kombinacije ter nove/stare konflikte $\mathrm{v}$ času takih sprememb in $\mathrm{v}$ na novo vzpostavljenih konstelacijah.

Že bežen pogled od zunaj v načela različnih religij in v zgodovinsko izkustvo pokaže, da so različne religije imele in imajo težave z omenjenimi sekularnimi načeli in da so se ta načela v zgodovini in sodobnosti praviloma uveljavljala preko spopadov z različnimi verskimi skupnostmi in ustanovami (Joas in Wiegandt, 2007). Toda ne glede na zgodovinsko izpričane težave je mogoče spoznati in pripoznati, da so jih vsaj vse velike, "svetovne« religije zmožne sprejeti ali vsaj tolerirati, najti modus vivendi z njimi. Mogoče je namreč zagovarjati in dokumentirati tezo, da prav velike svetovne in zgodovinsko uveljavljene religije poleg svojih dominantnih značilnosti in usmeritev vedno vključujejo tudi njim tako rekoč nasprotne in s tem (z)možnost drugačnega delovanja ter učinkovanja. Lahko bi rekli, da so velike svetovne in zgodovinske religije to postale in ostale prav zaradi te svoje (z)možnosti. (Judovska religija je lahko postala religija tudi nekaterih nejudovskih narodov in držav, in- 
dividualistično protestantsko krščanstvo je ponekod dalo spodbude in sredstva za oblikovanje močnih nacionalnih skupnosti, hierarhizirano in kolektivistično katoliško krščanstvo je omogočalo individualno mistiko, univerzalistični islam je postal nacionalna ideologija ...). Velike svetovne religije so postale svetovne, ker so bile sposobne »inkulturiranja« v še tako različne kulture in ker so bile sposobne vključiti različne kulturne elemente v svoje načine obstoja in delovanja. Isto lahko rečemo za velike zgodovinske spremembe kultur in civilizacij: velike religije so bile zato sposobne preživeti stoletja in tisočletja.

Lahko bi tvegali trditev, da za velike religije tako rekoč ni mogoče reči: to in to je nezdružljvo $z$ njimi - pa čeprav to ne pomeni, da je vse enako združljivo in sprejemljivo. Zunanje prilagajanje in notranje spremembe so vedno spremljale notranje razprave, delitve in spopadi brez »dokončnega« izida.

Ta gotovo zelo splošna ugotovitev seveda zahteva - a tudi omogoča - konkretno analizo zmožnosti delovanja različnih religij in verskih skupnosti v različnih kontekstih, torej tudi islama in islamskih skupnosti, ustanov in vernikov-muslimanov v sodobnih sekulariziranih in perspektivnih evropskih razmerah. Kako je s to zmožnostjo pri islamu, odgovarjajo s svojo življenjsko prakso in razumevanjem islamskih besedil prvenstveno seveda muslimani sami. Gledano od zunaj pa lahko tudi drugi opazimo, da islam pozna vrsto načel in napotil, ki so v soglasju in ki olajšujejo vključevanje muslimanov v sekularizirani družbeni kontekst: poznano je koransko načelo, da »v veri ni prisile« $(2,256)$; pa opozorilo, da

"ni pobožnosti v tem, da pri molitvi obračate obličje proti vzhodu ali zahodu, pač pa so pobožni tisti, ki verujejo v Boga in poslednji dan, v angele in v Knjigo in v preroke in dajejo od svojega premoženja sorodnikom, sirotam, ubogim, sinovom poti, beračem, za osvoboditev sužnjev, opravljajo molitev, darujejo miloščino, izpolnjujejo obljube, s katerimi so se zavezali, so potrpežljivi v nesreči, stiski in vojni ujmi: ti so pošteni in bogaboječi« $(2,177)$; 
ne gre prezreti tudi opozoril, da želi Bog z razodetjem ljudem olajšati in ne otežiti življenje, Prerokovega hadisa, ki pravi, »[...] olajšajte in ne otežujte, razveselite in ne užalostite« (Kardavi 2004, 75-61).

$\mathrm{Na}$ drugi strani pa so tudi od zunaj hitro opazne težave v praksi in $\mathrm{v}$ vplivnih interpretacijah. Danes izstopajo vprašanja, povezana $z$ žensko enakopravnostjo in razumevanjem verske svobode. Muslimanom ni dopuščeno, da bi svobodno sprejeli drugo vero: odpadnikom se grozi s kaznovanjem, od razveze zakonske zveze do smrtne kazni, o kateri naj bi v preteklosti soglašale vse uleme, razen tistih iz hanefijske šole (Kardavi 2004, 110); islamske države prepovedujejo misijonarjenje drugih religij, med muslimani sploh. Če/ker je v razmerah večinskega muslimanskega prebivalstva predpostavljeno delovanje države kot islamske države in delovanje njenih ustanov po islamskih/šeriatskih zakonih - torej neločenost države in religije -, to vzbuja nezaupanje in bojazni, da je islamsko sprejemanje sekularnih načel v Evropi zgolj začasno in taktično, po logiki: od vas zahtevamo svobodo v imenu vaših načel (ko/kjer smo šibka manjšina), vam pa jo odrekamo v imenu naših načel (ko/kjer smo močna večina).

Problemi pri vključevanju islama in muslimanov v moderni evropski kontekst očitno so. Optimizma , da so razrešljivi, pa ne daje le zgoraj omenjeno splošno zaupanje $\mathrm{v}$ zmožnosti velikih religij za inkulturacijo, ampak tudi zgodovinsko izkustvo krščanstva v Evropi sami. Pogledi in dileme, ki jih danes opažamo v zvezi z žensko enakopravnostjo in razumevanjem verske svobode, so v zvezi z ločenostjo države in verske skupnosti poznane tudi krščanski, posebej katoliško krščanski Evropi iz ne tako davne preteklosti. Tudi v njej so vse do predzadnjega stoletja prevladovala napotila apostola Pavla: žena bodi možu pokorna, moški je glava ženske ..., v cerkvi naj ženske molčijo (1 Kor 11,2; 14,34-35), v cerkvi in sicer naj bodo tudi obvezno pokrite (1 Kor 11,5-8). Sociološko in kulturološko gledano bi bilo ustrezneje reči: tudi v krščanski Evropi so se za opravičevanje ženske neenakopravnosti v družbi in v cerkvi uporabljala/ zlorabljala verska besedila (kot so Pavlova pisma). Potrebne so bile notranje cerkvene reforme - na primer Luthrova $\mathrm{z}$ načelom splošnega duhovništva vseh vernikov - in dolgotrajni procesi družbenih in kulturnih 
sprememb, povezanih z moderno proizvodnjo in izobraževanjem, da se je tudi v krščanskih cerkvah uveljavilo kot temeljno prav tako Pavlovo spoznanje: "Ni ne Juda ne Grka, [...] ni ne moškega, ne ženske, kajti vsi ste eden v Kristusu Jezusu « $(\mathrm{Gal} 3,28)$ in da imamo danes tudi ženske duhovnice ter škofinje vsaj v protestantskem krščanstvu.

$\mathrm{V}$ katoliškem krščanstvu še v 19. in 20. stoletju srečamo izrecno nasprotovanje ločenosti države in cerkve, nasprotovanje verski nevtralnosti državnih ustanov in verski svobodi za krščanske »herezije«, kaj šele za druge religije. V Syllabusu Pija XI. iz leta 1864 beremo, da se Cerkev nikdar ne bo sprijaznila $\mathrm{z}$ "napredkom, liberalizmom in moderno civilizacijo«; zavračana in obsojana je ločitev cerkve in države, prav tako z zakonom dovoljeno javno protestantsko bogoslužje priseljencev v katoliških deželah itd. (Denzinger 1991, 798-809). Še v 2. polovici 20. stoletja je bilo v Katoliški cerkvi slišati avtoritativna mnenja, da se je z ločitvijo cerkve in države (npr. v ZDA) iz pragmatičnih razlogov sicer treba sprijazniti, toda $v$ načelu jo je treba zavračati, saj da je »Cerkvi lahko popolnoma pravična le država, ki Cerkev prizna za to, kar je, namreč ustanova učlovečenega Boga Jezusa Kristusa: takšna država je samo verna katoliška država« (Ahčin 1955, 400). Še na II. vatikanskem koncilu je bilo slišati, da »zmota ne more imeti enakih pravic kot resnica«, pa da mora država, ki skrbi za svoje državljane, v njihovo dobro podpirati edino pravo religijo in cerkev (Kerševan 2005, 229-31). Pogledi in praksa, ki niso daleč od stališč, ki jih danes srečamo v islamskem svetu! Pa vendar je II. vatikanski koncil uspel sprejeti Izjavo o verski svobodi, utemeljeni v dostojanstvu vsakega človeka; spoštovanje dostojanstva človeka kot osebe je temelj posameznikove verske svobode nasproti državi ter ločenosti cerkve in države (ob njunem medsebojnem spoštovanju in sodelovanju). Krščanske cerkve, vsekakor katoliška, so v času francoske revolucije zavračale gesla o svobodi, enakosti in bratstvu ter deklaracije o pravicah človeka in državljana. Pa vendar so jih tudi v uradnih cerkvenih krogih kasneje spoznali in pripoznali kot krščanska načela. Ne vidim razloga, da jih ne bi bilo mogoče sprejeti in pripoznati tudi kot islamska. Tako abstraktna kot zgodovinska primerjava trikota katoliško krščanstvo - protestantsko krščanstvo - islam ( $\mathrm{z}$ upoštevanjem sunit- 
skih in šiitskih razhajanj) pokaže podobnosti in razlike med njimi, ki glede zmožnosti sprejetja omenjenih modernih značilnosti nikakor niso enoznačno v prid ali škodo zgolj enega od njih.

\section{»Sistemski« pristop}

Nekatera vprašanja »islama v sekularizirani Evropi« se na novo pokažejo ob "sistemskem" pristopu: sistemskem v smislu izhajanja iz deklarirane/sistemske ureditve Evropske unije, iz opredelitve njenih temeljnih načel in vrednot (relevantnih za našo problematiko) v njenih dokumentih.

V sistemskih dokumentih Evropske unije (kot je sicer nesprejeta Pogodba o ustavi in zato še veljavna Amsterdamska pogodba in Listina o temeljnih pravicah Evropske unije iz Nice) so navedene temeljne, konstitutivne evropske vrednote in načela, npr. v preambuli Listine:

Unija, ki se zaveda svoje duhovne (v nemški verziji: duhovno-religiozne) in moralne dediščine, je ustanovljena na nedeljivih in univerzalnih vrednotah človekovega dostojanstva, svobode, enakosti in solidarnosti; temelji na načelih demokracije in pravne države. $V$ središče svojega delovanja postavlja osebo/posameznika [...]. Unija prispeva $\mathrm{k}$ ohranjanju in razvoju teh skupnih vrednot ob spoštovanju različnosti kultur in tradicij evropskih narodov kot tudi nacionalnih identitet držav članic. (Listina [2000] 2003, 53)

Osnutek ustavne pogodbe $\mathrm{v}$ drugem členu izrecno navaja:

Unija temelji na vrednotah spoštovanja človekovega dostojanstva, svobode, demokracije, enakosti, pravne države in spoštovanja človekovih pravic. Te vrednote so skupne vsem državam članicam v družbi, v kateri vladajo pluralizem strpnost, pravičnost, solidarnost in nediskriminacija. (Osnutek 2003, 9)

Preambula Osnutka kot »vrednote, na katerih sloni humanizem«, navaja: »enakost oseb, svobodo, spoštovanje razuma«. V preambuli se go- 
vori tudi o »črpanju navdiha iz kulturnega, verskega in humanističnega izročila Evrope, katerega vrednote so še vedno prisotne v njeni dediščini«. (Osnutek 2003, 5)

Kot je znano in razvidno iz citiranega besedila, dokumenti Evropske unije ne govorijo izrecno o krščanstvu (kot »tradiciji« ali »korenini« sedanje evropske dediščine in evropskih vrednot). Kljub dolgotrajnim razpravam in spodbudam s strani krščanskih cerkva in nekaterih držav v dokumente tudi ni bilo sprejeto sklicevanje na Boga (kot izvora in/ali garanta omenjenih vrednot in načel, ali vsaj kot priče, ki zavezuje k spoštovanju sprejetih vrednot). Lahko bi rekli, da je bilo v teh dokumentih doseženo/izrečeno soglasje o skupnih, zavezujočih vrednotah kot konstitutivni in povezovalni kulturni ravni Evropske unije (glej tudi Joas in Wiegandt 2005, in še posebej za Nemčijo Klinkhammer in Frick 2002). Kot prostor svobode in izbire, v katerega Unija ne posega, kjer ničesar ne izključuje, a tudi ne zapoveduje, pa je ostala (naj)višja raven, raven "zadnjih", metafizičnih verskih/svetovnonazorskih vprašanj in odgovorov; odprto je ostalo vprašanje »temelja«, »izvora«, "zadnjega zagotovila« omenjenih vrednot in načel. V tem smislu Evropska unija ni religiozna, temveč sekularna/laična ureditev, saj se ne veže na nobeno religijo. Ob tem pa tudi ni ateistična ali agnostična ali vrednotno relativistična, saj ne predpostavlja/izjavlja, da omenjene temeljne vrednote niso združljive z nobeno religijo ali nazorom. Nasprotno: predpostavlja, da jih je mogoče povezati, utemeljiti, podpreti $z$ različnimi religioznimi in nereligioznimi pojmovanji, še več, da je pluralizem možnih odgovorov na vprašanje izvora in temelja njenih vrednot tem vrednotam in njihovi trdnosti v prid in ne v oviro. »Svetovni etos svetovnih religij«, ki ga je poskušal formulirati Hans Küng, je potrditev ali vsaj ilustracija tega (Küng 1993; tudi Khoury 1993).

O tem, ali temeljne vrednote za svoj obstoj in trdnost potrebujejo še "zadnjo«, metafizično utemeljitev, se pogledi razhajajo. Po nekaterih gre za tako samoumevne vrednote, da neke take utemeljitve ne potrebujejo: imajo naravo pred-sodka v pozitivnem smislu, ne pa rezultata raziskovanja, diskusij in presojanja. Po drugih se vzdržujejo same, ker so nerazdružno povezane $\mathrm{z}$ elementarnimi medčloveškimi odnosi in ko- 
munikacijskimi procesi. Nekateri pa prav zaradi njihove pomembnosti in ranljivosti poudarjajo potrebo po njihovi utemeljitvi in vzdrževanju s pomočjo (naj)višjih ali (naj)globljih metafizičnih načel, ki jih nudijo različne religije in svetovni nazori. V tem smislu se tolmači znana teza/ spoznanje, da »svobodna demokratična sekularna država živi od predpostavk, ki jih sama ne more zagotoviti« (Böckenförde) (Kerševan 2005, 65-69).

$\mathrm{Na}$ tem mestu se seveda ne bi spuščali v te razprave. Dovolj je konstatacija, da ne gre za medsebojno izključevanje razlag, za ali-ali. Tudi če vrednote niso nujno vezane na religijo in še posebej ne na le eno od njih, jim religije lahko nudijo bolj ali manj pomembno oporo.

Odprta za religijsko (kulturno, jezikovno, etnično) raznolikost, torej nezavezujoča, pluralizmu in avtonomiji prepuščena, ostaja po EUdokumentih tudi raven kulturnih (in verskih) tradicij, življenjskih stilov, norm in vrednot. Tiha predpostavka pri tem je, da niso v nasprotju s skupnimi, zavezujočimi vrednotami in pravicami. »Unija prispeva $\mathrm{k}$ ohranjanju skupnih vrednot ob spoštovanju različnosti kultur in tradicij evropskih narodov kot tudi nacionalnih identitet držav članic." (Listina [2000] 2003, 53) Unija "spoštuje svojo bogato kulturno in jezikovno raznolikost ter skrbi za varovanje in razvoj evropske kulturne dediščine" (Osnutek 2003, 10). Pri tem "spoštuje in ne posega v status, ki ga cerkve in verska združenja ali skupnosti uživajo v državah članicah po notranjem pravu« (Osnutek 2003, 43). In dalje: »Unija, ki tem cerkvam in organizacijam priznava njihovo identiteto in njihov specifični prispevek, z njimi vzdržuje odprt, pregleden in reden dialog." (Osnutek 2003, 43)

Vprašanje mesta in vloge neke religije ( $\mathrm{v}$ našem primeru islama) znotraj take ureditve se tako postavlja na treh ravneh:

- na ravni zavezujočih vrednot: ali jih neka religija in njeni pripadniki sprejemajo, jih imajo za svoje ali jim vsaj ne nasprotujejo in ne delujejo proti njim;

- na ravni zadnjih religioznih in nazorskih utemeljitev: ali neka religija zmore, ali njeni pripadniki iščejo in hočejo najti v njej zadnje, božje utemeljitve za te vrednote, ali, nasprotno, tega ne zmore ali tega nočejo (ker jih nimajo za svoje); 
- na ravni v Evropi, natančneje v EU, obstoječih kultur in tradicij njenih narodov in okolij: ali neka religija že obstaja znotraj teh kultur in tradicij in je zato deležna spoštovanja kot del evropske kulturne dediščine in njene spoznane ter spoštovane raznolikosti; ali se je zmožna in pripravljena »inkulturirati« (tudi) vanjo/vanje, se pravi, ali so tega zmožni in voljni njeni, v različne druge kulture in tradicije inkulturirani pripadniki (v našem primeru muslimani)?

Po že povedanem lahko rečemo, da islam in muslimani lahko sprejemajo omenjene vrednote ter lahko iščejo in najdejo njihove višje/globlje utemeljitve, opravičenja in osmislitve v svoji religiji; odprto ostaja vprašanje, ali in kako taka religiozna utemeljitev/osmislitev na poseben način interpretira in usmerja uresničevanje teh vrednot in načel.

Težje je vprašanje, ali in kako muslimani (že vključeni v različne evropske ali neevropske kulture in tradicije) razumejo razmerje/napetost med obvezujočimi skupnimi vrednotami EU (in z njimi povezanimi, posebej poudarjanimi pravicami posameznika) ter kolektivnimi vrednotami in doživljanimi interesi svojega naroda, etnije, lokalne skupnosti, rodbine, v katere so vključeni. Seveda to vprašanje nikakor ne zadeva le islama in muslimanov, ampak tudi pripadnike drugih religijskih skupnosti in kulturnih tradicij, gotovo pa je to za islam in muslimane v Evropi še posebej relevantno vprašanje in poseben izziv. Muslimani kot priseljenci so po eni strani deležni verske svobode in siceršnjih pravic, povezanih s temeljnimi skupnimi vrednotami in načeli, po drugi strani pa (še?) niso del obstoječe kulturne (verske), jezikovne in etnične raznolikosti Unije, »kultur in tradicij evropskih narodov« in »evropske kulturne dediščine« (ki tudi same niso vnaprej in nujno usklajene $\mathrm{z}$ deklariranimi, zavezujočimi skupnimi vrednotami!). Če smo že uvideli nesporno možen pozitiven odgovor o mestu in vlogi islama z ozirom na skupne vrednote in njihovo utemeljevanje, očitno ostajajo odprta vprašanja in izzivi prav na tej tretji ravni in njenem razmerju do prvih dveh. Poseben izziv in posebna priložnost ter obveznost je tu pred bosanskimi (in drugimi balkanskimi) muslimani, ki so že več stoletij del »kulturne in jezikovne raznolikosti«, »različnosti kultur in tradicij evropskih na- 
rodov« in »evropske kulturne dediščine« (drugače kot novejši priseljenci in migranti ali začasni begunci). ${ }^{2}$

\section{»Zgodovinski« pristop}

Poudarjanje zgodovinske/časovne dimenzije pri obravnavanju vprašanja islama $v$ Evropi nas običajno usmeri na izhodiščno ugotovitev/ tezo, da je Evropa, taka kot je v zgodovini nastala, »krščanska» (s »krščanskimi koreninami«). Seveda razprava o krščanskih koreninah in značaju/identiteti Evrope ne more mimo upoštevanja judovske komponente krščanstva, pa grško-rimskih sestavin že samega krščanstva in mimo njega, ne more mimo posledic inkulturacije krščanstva v siceršnji mediteranski, germanski, tudi slovanski svet; natančnejše preučevanje ne pozabi tudi vpliva arabsko-muslimanskega prispevka k evropski kulturi v času formiranja evropskega krščanstva in spodbud, ki so jih za oblikovanje skupne evropske/krščanske zavesti pomenile muslimanska, arabska in turška ekspanzija v zgodovini. Toda za našo temo - islam v sekularizirani Evropi - je tokrat še pomembnejše dejstvo, da so se značilnosti te sodobne sekularizirane Evrope izoblikovale znotraj »krščanske Evrope «, kot rezultat razvoja, delitev in sprememb znotraj krščanstva, kot produkt idejnih in političnih spopadov znotraj njega in v zvezi z njim. ${ }^{3}$ Ne moremo mimo zgodovine odnosov, ki so privedli do oblikovanja »krščanske države« že v času rimskega imperija, mimo razmerja med imperijem in papeštvom, med državo in cerkvijo sploh; reformacije $\mathrm{z}$ njenim pojmovanjem svobode vere notranjega človeka in njeno

2 Rad bi na tem mestu posebej opozoril na delo sarajevskega profesorja in sociologa religije Ivana Cvitkovića z zgovornim naslovom Moj sosed musliman: delo gradi in želi graditi na življenjskem izkustvu sobivanja v Bosni, ki ga vključuje v sociološko refleksijo aktualnih kontraverz o(b) »islamu v Evropi« (ob obsežni domači bosanski muslimanski in svetovni strokovni literaturi). Gl. Cvitković 2011, 17793, 211-30.

3 O sekularizaciji, krščanstvu in islamu ob sodobnih političnih konfrontacijah "Zahoda" in "muslimanskega sveta« piše pri nas Primož Šterbenc v knjigi Zahod in muslimanski svet: akcije in reakcije (Šterbenc 2011, 40-92, 105-68). 
subverzijo oblastne cerkve, oblasti cerkvene hierarhije znotraj cerkve; uveljavljanja nacionalnih držav in nacionalnih cerkva; znotrajkrščanskih verskih vojn in njihovega preseganja $\mathrm{z}$ razsvetljenstvom in njegovo kritiko - od znotraj in od zunaj - krščanske religije s sklicevanjem na razum kot instanco onkraj spopadajočih se religijskih usmeritev; afirmacije pravic človeka in državljana ne glede na religiozno pripadnost, uveljavljanja svetovnonazorske in verske nevtralnosti države, afirmacije enakopravnosti žensk.

Govoriti danes o krščanski Evropi, o krščanskosti Evrope, ne da bi upoštevali njeno sekulariziranost - ta ni prišla od zunaj, temveč je nastala kot način razreševanja njenih notranjih dilem -, pomeni govoriti o Evropi brez rešitev, ki jih je v svojem razvoju našla v soočanju s »svojo « dominantno religijo in znotraj nje. V zgodovinskih procesih se je kot »strukturna rešitev« bolj ali manj razločno izoblikovalo razlikovanje med področjem države (obveznih, tudi s prisilo podprtih dejavnosti), področjem zasebnosti in vmesnim področjem javnosti, civilne družbe, $\mathrm{v}$ kateri se srečujejo svobodni posamezniki in raznovrstna združenja. $\mathrm{Z}$ ozirom na religijo bi lahko rekli, da gre na enem polu za sekularno državo in njene obvezne ustanove, kjer dominira načelo negativne verske svobode: nihče ne sme biti prisiljen k neki religiji ali proti njej, kaznovan ali diskriminiran zaradi nje. Na drugem polu je zasebnost kot področje svobode, avtonomne, nesankcionirane verske izbire in odločanja. Vmes je ožje ali širše področje javnosti, civilne družbe, kot področje svobodnega izpovedovanja in življenjskega izražanja religije in religijske pripadnosti, v katero država (s svojim pravnim redom in prisilo) posega le, da/ko preprečuje uporabo prisile in zagotavlja pravni red in mir pri zagotavljanju temeljnih pravic, ki enako pripadajo vsem državljanom/ prebivalcem.

$\mathrm{Na}$ tem vmesnem področju se srečujeta in soočata pozitivno in negativno pojmovanje verske svobode - svoboda izpovedovanja in udejanjanja religije in svoboda od verske prisile (s strani drugih). Lahko bi rekli, da je to področje, kjer se oblikujejo konkretne meje in mere razmerja med pozitivno in negativno svobodo; področje, kjer se oblikujeta konkretna stopnja in mera medsebojne (ne)tolerance udeležencev. 
Opazno je, da sta pri tem mogoči dve usmeritvi (Beck 2009, 144). Po prvi naj bo tolerance, kolikor je nujno (da ne pride do nasilja, da se lahko živi skupaj v miru), netolerance (do drugačnosti, drugače verujočih, odpadnikov), kolikor je le možno. Druga usmeritev je usmeritev k toleranci, kolikor jo je čim več mogoče, in k omejitvi netolerance na mero, ki je zares nujna (da se ohrani lastna identiteta, da se prepreči zrušenje prostora svobode zaradi prevelike tolerance do netolerantnih). Očitno pa so meje med dojemanjem možnosti/nujnosti, dopustnosti/prepovedovanja nekaj gibljivega in spremenljivega $\mathrm{v}$ času ter prostoru.

Meje med področji nevtralne sekularne državnosti, nedotakljive zasebnosti in svobodnega javnega prostora (ne)izražanja religije so spremenljive. Omenjane zavezujoče skupne vrednote in načela (človekove pravice) pa naj bi zagotavljale, da se delitev na ta področja vendarle ohranja in da se meje med njimi ne premikajo tako, da bi ogrozile obstoj katerega od njih. Na primer, tudi če se neka država še veže na določeno religijo, (krščansko) religijsko simbolno tradicijo in podobno (kar je v Evropi pogosto), to ne sme pomeniti diskriminacije državljanov drugih religij ali ateistov pri uveljavljanju njihovih pravic. Ali: tudi če v neki družbi ali družbeni skupini - na primer družini ali lokalni skupnosti dominirajo posebne tradicije, vrednote in norme neke verske skupnosti, mora država z zakoni zaščititi (svobodo) posameznika, ki te tradicije, norme in vrednote_zavrže oziroma opusti pripadnost taki skupnosti.

\section{Namesto (do)končnega sklepa}

Kakšen problem in izziv predstavlja za tako sekularizirano Evropo islam s svojimi značilnostmi in z lastnimi notranjimi variacijami ter različnimi podedovanimi inkulturacijami; kakšen izziv pomeni taka sekularizirano krščanska Evropa za sedanji islam, za njegovo (z)možnost odgovarjati na zahteve in težave zanj nove inkulturacije?

Glavno področje preverjanja te zmožnosti, vključno s sposobnostjo samoomejevanja, je področje javnosti/civilne družbe. Vsaj v evropskem, manjšinskem položaju muslimani ne morejo želeti, da bi država postala 
nesekularna, se pravi vezana na neko religijo, saj bi bila ta $\mathrm{v}$ tem primeru pač krščanska. Islam lahko sprejema skupne vrednote EU in jih tudi sam religiozno utemeljuje. V sferi »čiste zasebnosti« se muslimanom ni treba bati za versko svobodo - svobodo vere kot bistveno notranje/intimne človekove zadeve. Problem (ne)tolerance se začne, ko se izpovedovanje vere izraža v družinskih, meddružinskih in lokalnih odnosih (ter $\mathrm{s}$ tem tako ali drugače vstopi v javnost).

Lahko bi rekli, da je najmanj težav z/s (ne)toleranco pričakovati tam, kjer je religioznost dojemana kot izrazito notranja osebna zadeva, (skoraj) brez posebnih zunanjih izrazov, ali tam, kjer je izrazito ritualizirana, prakticirana (skoraj) zgolj v posebnih sakraliziranih prostorih in časih. Prva usmeritev je blizu protestantskemu krščanstvu, druga pravoslavnemu. Vprašanje (ne)tolerance je toliko akutnejše, kolikor bolj se religioznost izraža $\mathrm{v}$ posebnih normah in ravnanjih $\mathrm{v}$ družinskem, meddružinskem, poklicnem in krajevnem življenju (in v tem okviru tudi v posebnih prehrambenih in oblačilnih predpisih): očitno v večji meri $\mathrm{v}$ katoliškem krščanstvu, judaizmu in islamu - pri čemer so lahko mnoge od takih posebnih norm in ravnanj posledica že tradicionalne inkulturacije teh religij v določena etnična in lokalna okolja preteklih obdobij. Pripadniki izraziteje ponotranjenega ali izraziteje ritualiziranega pojmovanja religioznosti - oboji so navajeni na (samo)omejevanje izražanja vernosti v posvetnem življenju - težko razumejo vztrajanje pripadnikov teh usmeritev pri njihovih posebnih »zunanjih« normah in obnašanjih kot bistveno religioznih zadevah. V tem smislu je usmeritev k raz-vezanju bistvenih verskih norm od etničnih in kulturnih tradicij lahko razbremenilna, saj olajšuje ohranjanje in izražanje verskih identitet na eni strani ter ohranjanje (ali opuščanje) nekih norm in ravnanj zgolj kot sestavin etnične tradicije in folklore, na drugi strani. Seveda pa je to $\mathrm{v}$ zgodovinski konkretnosti povezano $\mathrm{z}$ dilemo: ali naj se neka skupnost $v$ novem/tujem okolju ohranja prvenstveno kot etnična skupnost/manjšina (katere sestavina/opora je tudi posebna religija in njeni izrazi), ali pa naj se njena religija odpre nasproti večinskemu okolju in njegovim pripadnikom ter opusti dotedanjo vezanost na svoje tradicionalno etnično kulturno in jezikovno okolje. 
Vsa ta razmerja, s spremljajočimi napetostmi in konflikti vred, se umeščajo v prostor med državnostjo in zasebnostjo, v prostor (javnosti), ki je ravno prostor vseh tistih kulturnih raznolikosti, različnih kultur in tradicij, nacionalnih in drugih identitet in z njimi povezanih skupnosti - etničnih, lokalnih, rodbinskih, lahko tudi poklicnih -, ki so se v preteklosti v različnih obdobjih in okoljih prepletle ali celo zlile $\mathrm{z}$ verskimi $\mathrm{n}$ se temu primerno preoblikovale. Kot takega moramo ta prostor videti in upoštevati tudi pri obravnavanju vprašanja islama (in drugih religij) v sodobni sekularni Evropi. Njegova kompleksnost in zgodovinska odprtost nam onemogočata, da ne rečem prepovedujeta, da bi na tem mestu izrekli kaj več od zgornjih opozoril na dileme in perspektive. Naj namesto zaključka, ali na mestu zaključka, še enkrat poudarim svoje prepričanje, da je »sekularna« Evropa - ob vseh problemih, ki jih je treba upoštevati - s svojimi težko pridobljenimi in uveljavljenimi načeli zmožna (p)ostati normalen življenjski prostor tudi za islam in muslimane in da je po drugi strani islam zmožen sprejeti tako Evropo za enega svojih življenjskih prostorov.

\section{LITERATURA}

Ahčin, Ivan.1955. Sociologija 2, 2. Buenos Aires: Družabna pravda.

Barth, Karl. (1946) 2016. „Skupnost kristjanov in skupnost državljanov«. Stati inu obstati: revija za vprašanja protestantizma 12 (23-24): 263-94.

Beck, Ulrich. 2009. Lastni Bog: O zmožnosti religij za mir in njihovem potencialu za nasilje. Ljubljana: Claritas.

Corm, Georges. 1977. Prilog proučavanju multikonfesionalnih društava. Sarajevo: Svjetlost.

Cvitković, Ivan. 2011. Moj susjed musliman. Zagreb: Školska knjiga.

Denzinger, Heinrich, ur. 1991. Enchiridion ... de rebus fidei et morum. Lat.-nem. 37. izd. Freiburg: Herder.

Joas, Hans, in Klaus Wiegandt, ur. 2005. Die kulturellen Werte Europas. Frankfurt am Main: Fischer Verlag

---, ur. 2007. Säkularisierung und die Weltreligionen. Frankfurt am Main: Fischer Verlag. 


\section{ŠTUDIJSKI VEČERI}

Kardavi, Jusuf el-. 2004. Fikh muslimanskih manjina: kako biti musliman na Zapa$d u$. Sarajevo: Libris.

Kerševan, Marko. 2005. Svoboda za cerkev, svoboda od cerkve: Cerkev in sodobna družba. Ljubljana: Sofija.

Khoury, Adel Theodor. 1993. Das Ethos der Weltreligionen. Freiburg: Herder.

Klinkhammer, Gritt, in Tobias Frick, ur. 2002. Religionen und Recht. Marburg: Diagonal Verlag.

Koran o Koranu, Bogu, islamu ... . 2003. Ureditev in spremna beseda Marko Kerševan, izbor in prevod koranskih besedil Nina Svetlič. Ljubljana: Cankarjeva založba.

Kramer, Gudrun. 2003. "'Der Islam ist Religion und Staat': Zum Verhältnis von Religion, Recht und Politik im Islam.« V Fundamentalismus, Terrorismus, Krieg, ur. Wolfgang Schluchter, 45-61.Weilerswist: Velbrück Wissenschaft.

Küng, Hans, in Karl-Josef Kuschel. 1993. Erklärung zum Weltethos: Die Deklaration des Parlamentes der Weltreligionen. München: Piper.

Listina o temeljnih pravicah Evropske Unije. (2000) 2003. V Osnutek Pogodbe o ustavi za Evropo. Luksemburg: Urad za uradne publikacije Evropskih skupnosti.

Osnutek Pogodbe o ustavi za Evropo. 2003. Luksemburg: Urad za uradne publikacije Evropskih skupnosti.

Šterbenc, Primož. 2011. Zahod in muslimanski svet: akcije in reakcije. Ljubljana: Založba FDV.

https://doi.org/10.26493/2590-9754.14(28)167-182 